\title{
Anti-Sperm Antibodies: Risk Factors of Positive Serology among Infertile Men Patients in Kisangani-Democratic Republic of Congo
}

\author{
Maindo Alongo Mike-Antoine ${ }^{*}$, Juakali Sihalikyolo1, Salomon Batina Agasa2, \\ Antoine Modia O'yandjo1, Bernard Mbutu³, Gédéon Katenga Bosunga1, \\ Jean-Pascal Manga Okenge ${ }^{1}$
}

\footnotetext{
${ }^{1}$ Department of Obstetrics and Gynecology, Faculty of Medicine, University of Kisangani, Kisangani, Democratic Republic of Congo

${ }^{2}$ Department of Internal Medicine, Faculty of Medicine, University of Kisangani, Kisangani, Democratic Republic of Congo ${ }^{3}$ Intitut Superieur des Techniques Médicales de Kisangani, Ema Esu Laboratory, Kisangani, Democratic Republic of Congo Email: *maindo21@gmail.com
}

How to cite this paper: Maindo A., M.-A., Sihalikyolo, J., Agasa, S.B., O'yandjo, A.M., Mbutu, B., Bosunga, G.K. and Okenge, J.-P.M. (2019) Anti-Sperm Antibodies: Risk Factors of Positive Serology among Infertile Men Patients in Kisangani-Democratic Republic of Congo. Open Journal of Obstetrics and Gynecology, 9, 1130-1141. https://doi.org/10.4236/ojog.2019.98109

Received: June 30, 2019

Accepted: August 6, 2019

Published: August 9, 2019

Copyright $\odot 2019$ by author(s) and Scientific Research Publishing Inc. This work is licensed under the Creative Commons Attribution International License (CC BY 4.0).

http://creativecommons.org/licenses/by/4.0/ (c) (i) Open Access

\begin{abstract}
Introduction: Antisperm antibodies (ASA) prevalence is high in Kisangani. ASA are one of the male factors of infertility that can reduce spermatozoa motility and cervical penetration or prevent acrosomal reaction and even alter embryo development. This study aims to determine the risk factors of ASA positivity among infertile men in Kisangani. Patient and Method: We conducted a case-control study during a period of 2 years in Kisangani on 111 men who consulted for conception and tested for ASA by ELISA. We did a simple pairing that concerned only the type of infertility. For a better balance between the number of cases and controls per stratum to provide better accuracy in the adjusted OR estimate, we performed a 1:1 match. Results: This study showed that businessmen $[\mathrm{ORa}=5.0000(1.2452-20.0767)]$ and jobless $[\mathrm{ORa}=5.8125(1.1477-29.4367)]$ were at risk of being positive for ASA. Violent blow to testicles [ORa $=6.7391(1.3455-33.7545)$ ], cure of hernia $[\mathrm{ORa}=4.3478(1.0722-17.6299)]$, Chlamydia infection $[$ ORa $=$ $4.7125(1.3405-16.5665)]$, leucospermia [ORa $=4.1429(1.0406-19.7155)]$ and presence of Staphylococcus aureus $[\mathrm{ORa}=3.4444(0.6410-18.5082)]$ were associated to positive ASA. Conclusion: This study shows that factors that may lead to risky sexual behavior and physical or infectious trauma are important risk factors for ASA positivity. It is therefore necessary to search for them systematically during male infertility in order to guide the search for ASA.
\end{abstract}

\section{Keywords}

Antisperm Antibody, Chlamydia Trachomatis, Men Infertility, Immune 
Infertility, Infertility, Democratic Republic of Congo

\section{Introduction}

Infertility is a disease defined by the lack of clinical conception after 12 months or more of unprotected sexual intercourse, satisfactory in quantity and quality and at appropriate times or after treatment with insemination using donor sperm [1] [2] [3]. Failure to conceive can lead to stress, depression, discrimination, ostracism, economic problems... [4] [5] [6]. For the man, his inability to conceive often means that his virility and sexual power are affected. In African culture it is heavy to carry infertility, especially since the father transmits his name [7] [8]. "Male factor" infertility is seen as an alteration in sperm concentration and/or motility and/or morphology in at least one sample of two sperm analyses, collected 1 and 4 weeks apart [9]. Infertility due to male factor ranges from $20 \%$ to $70 \%$ and the percentage of infertile men ranged from $2.5 \%$ to $12 \%$. Africa and Central/Eastern Europe are the regions having the highest rate of male Infertility [10]. Males with sperm parameters below the WHO normal values are considered to have male factor infertility. The most significant of these are low sperm concentration (oligospermia), poor sperm motility (asthenospermia), and abnormal sperm morphology (teratospermia). As high as $90 \%$ of male infertility problems are related to count and there is a positive association between the abnormal semen parameters and sperm count [11] [12] [13]. Among factors that lead to alteration of sperm parameters, there are anti-sperm antibodies (ASA). They induce a decrease in motility of spermatozoa and their cervical penetration by agglutination. They also inhibit the acrosomal reaction by disturbing the membrane permeability of spermatozoa and they can even prevent the development of the embryo resulting in abortions. By attaching themselves to spermatozoa, ASA facilitate their recognition and phagocytosis by macrophages leading to oligospermia [14]-[20]. Globally the prevalence of ASA varies a lot around the world and can reach 64.4\% [21] [22] [23] [24] [25]. In man, Maria Khatoon and Col. [23] found 30.3\% of seropositivity in infertile men and B.I Adejumo et al. [26] found 22.7\%. Maindo and Col. in Democratic Republic of Congo found a prevalence of $29.72 \%$ [27]. Many factors have been cited as leading to the production of ASA. Among those factors, there is testicular trauma, cryptorchidism, hernia, infections, vasectomy,... [28]-[33].

The aim of this study is to determine risk factors of ASA positivity among infertile men in Kisangani.

\section{Patients and Method}

During the period of 2 years, from 1 January 2017 to 31 December 2018, we conducted a case-control study on 111 male patients who consulted for conception and in whom the search for circulating ASA in serum was performed. Apart 
from that, their medical files should have all data needed for this paper. For ASA search, approximately $5 \mathrm{ml}$ of the venous blood from each of the 111 patients was collected under an aseptic condition. For the separation of serum from whole blood, a centrifugation at $3000 \mathrm{rpm}$ was performed for 5 minutes. Once the serum was obtained, the analysis was performed immediately. If this was not possible, the sample was kept in a sterile tube at a temperature of $2^{\circ} \mathrm{C}-8^{\circ} \mathrm{C}$ until the time of analysis. The immunoglobulin test was performed by ELISA using the Stat $\mathrm{Fax}^{\circledast} 4700$ device. All the tests were carried out in the Ema Esu laboratory, the only one carrying out this test in the city. Patients with positive ASA serology for Ig A and/or Ig G were considered as cases and those with a negative serology were considered as control. We did a simple pairing that concerned only the type of infertility. For a better balance between the number of cases and controls per stratum to provide better accuracy in the adjusted OR estimate, we performed a 1:1 match. We included in this study infertile men with ASA research result and a medical file having necessary parameters studied in this paper. We excluded those who were in a relationship for less than 12 months and who had a medical file lacking data studied in this paper. Data were collected from medical and laboratory files were encoded using Excel. We used Epi Info ${ }^{\bullet}$ software version 7.2 for data analysis.

We performed a bivariate analysis to measure whether there was a statistically significant difference in the occurrence of an event between cases and controls in relation to a factor; we calculated Pearson's chi-square ( $p$-value). We considered that the difference was significant when $p$-value was less than 0.05 at the $95 \%$ threshold. When the terms of use of Pearson's chi-square were not applicable, we used the Fisher exact test at the 95\% threshold with significance when the Fisher exact was less than 0.05 .

To measure whether there was an association between the presence of a factor and the occurrence of an event and to evaluate the degree of this association, we performed a multivariate analysis with conditional logistic regression by calculating the adjusted Odd Ratio (ORa), and its 95\% confidence interval (CI).

\section{Results}

Table 1 shows that the majority of patients were had 41 years and over (50.45\%), were married (91.89\%), were civil servants (53.15\%) and had university level (40.54\%). In Table 2, according to clinical characteristics, the majority of patients in our study had primary infertility $(61.26 \%)$ with mean infertility duration of $7.33 \pm 5.06$ years. In their history, $13.51 \%$ had a violent testicle blow, $17.12 \%$ had cure of hernia and $4.50 \%$ had testicular torsion. There is a history of STIs among $23.42 \%$ of them. $5.41 \%$ of them have syphilis, $20.72 \%$ have chlamydia and $6.31 \%$ are positive for HIV. $61.26 \%$ of them had a spermogram abnormality. Spermogram abnormalities observed were asthenospermia (44.44\%), oligospermia (37.84\%), teratospermia (36.04\%) and pyospermia (15.32\%). Sperm culture revealed the presence of $C$. albicans alone in $6.31 \%$ of cases, $C$. albicans associated with $S$. aureus in $9 \%$ of cases and $S$. aureus alone in $9 \%$ of cases. 
Table 1. Socio-demographics characteristics of patients.

\begin{tabular}{ccc}
\hline Age $^{*}$ & & \\
\hline$\leq 30$ years & 12 & 10.81 \\
$31-40$ years & 43 & 38.74 \\
$\geq 41$ years & 56 & 50.45 \\
\hline Matrimonial status & & \\
\hline Single & 9 & 9.11 \\
Married & 102 & 91.89 \\
\hline Profession & & 53.15 \\
\hline Civil servant & 59 & 11.71 \\
Other & 13 & 16.22 \\
Businessmen & 18 & 9.91 \\
Jobless & 11 & 9.01 \\
\hline Motor bike transporter & 10 & \\
\hline Niveau d'étude & & 21.62 \\
Primary & 24 & 37.84 \\
O level & 42 & 40.54 \\
\hline University & 45 &
\end{tabular}

${ }^{*}$ Mean of age $=44.53 \pm 9.33$ years.

Table 2. Clinical characteristics of patients.

\begin{tabular}{lcc}
\hline & N & $\%$ \\
\hline Type of infertility* & & \\
$\quad$ Primary & 68 & 61.26 \\
$\quad$ Secondary & 43 & 38.74 \\
Presence of STDs\# & 26 & 23.42 \\
Chlamydia test+ & 23 & 20.72 \\
Syphilis test+ & 6 & 5.41 \\
HIV test+ & 7 & 6.31 \\
History of testicle trauma & 15 & 13.51 \\
Cure of hernia & 19 & 17.12 \\
History of testicular Torsion & 5 & 4.50 \\
Anomalies of spermogram & 68 & 61.26 \\
Asthenospermia & 49 & 44.14 \\
Oligospermia & 42 & 37.84 \\
Teratospermia & 40 & 36.04 \\
Leucospermia & 17 & 15.32 \\
Culture of sperm & & \\
$\quad$ C. albicans & & \\
$\quad$ C. albicans + S. aureus & 7 & 6.31 \\
$\quad$ S. aureus & 68 & 9.00 \\
$\quad$ Sterile & 70.28 \\
\hline
\end{tabular}

* Mean duration of infertility $=7.33 \pm 5.06$ years; \#STDs (sexually transmitted diseases) studied are C. trachomatis, Syphylis and HIV. 
As show us results in Table 3, we did not found an association between the level of study and ASA, yet according to profession, we found that being businessman or jobless multiplied respectively by 5 and almost 6 the risk of ASA positivity.

In Table 4, we found that duration of infertility was not associated to ASA positivity. History of testicular trauma was found multiplying by 6 the risk of ASA positivity and among testicular trauma, violent blow to the testicles and cure of hernia multiplied by 6.7 and 4.3 the risk of ASA positivity respectively. Past or current s sexual transmitted diseases multiply by 4.1 the risk of positive ASA. We found that only Chlamydia infection was associated to positive ASA and multiplied by 4.7 the risk of positivity. By analyzing sperm, our study showed that leucospermia multiplied by 4.1 the risk of positive ASA and that the presence of $S$. aureus in sperm culture multiplied by 5.8 the risk of ASA positivity.

\section{Discussion}

Empirically, we think that the more we are educated the less we adopt these risky behaviors. However, Clark P. and Kohler [34] in Malawi, Glynn et al. [35] in Benin, Gregson Zaddell and Chandiwana [36] in Zimbabwe and Hargreaves et al. [37] in South Africa found that the level of study high did not negatively influence the number of sexual partners. Also, Clark et al. [34] in Malawi and Mmbanga et al. [38] in Tanzania also did not find a positive relationship between level of study and condom use. These studies thus show that sexual behavior remains the same regardless of the level of education and therefore all men have the same degree of exposure to risky behavior that can lead to STDs, one of causes of ASA. This can explain why we did not find an association between level of education and ASA.

In our study, we found that businessmen and jobless were at high risk to have a positive ASA. Considering the fact that traders would usually have a short

Table 3. Socio-demographics characteristics and ASA serology.

\begin{tabular}{|c|c|c|c|c|}
\hline & $\begin{array}{l}\text { ASA+ } \\
\text { N (\%) }\end{array}$ & $\begin{array}{l}\text { ASA- } \\
\text { N (\%) }\end{array}$ & $\mathrm{p}$-value & ORa (CI à95\%) \\
\hline \multicolumn{5}{|l|}{ Level of study } \\
\hline Primary & $6(18.18)$ & $9(27.27)$ & 0.3782 & $0.3333(0.1568-0.7088)$ \\
\hline O level & $11(33.33)$ & $10(30.30)$ & 0.7915 & $0.4545(0.2152-0.9599)$ \\
\hline University & $16(48.48)$ & $14(42.42)$ & 0.6236 & $0.8235(0.4059-1.6707)$ \\
\hline \multicolumn{5}{|l|}{ Profession } \\
\hline Civil servant & $5(15.15)$ & $20(66.66)$ & 0.0001 & $0.1161(0.0357-0.3779)$ \\
\hline Other & $1(3.03)$ & $6(18.18)$ & $0.0524^{*}$ & $0.1406(0.0423-1.6414)$ \\
\hline Businessman & $11(33.33)$ & $3(9.09)$ & $0.0163^{*}$ & $5.0000(1.2452-20.0767)$ \\
\hline Jobless & $9(27.27)$ & $2(6.06)$ & $0.0219^{*}$ & $5.8125(1.1477-29.4367)$ \\
\hline Motor bike transporter & $7(21.21$ & $2(6.06)$ & $0.0743^{*}$ & $4.1731(0.7969-21.8529)$ \\
\hline
\end{tabular}


Table 4. Clinical and paraclinical parameters and ASA serology.

\begin{tabular}{|c|c|c|c|c|}
\hline & $\begin{array}{l}\text { ASA+ } \\
\text { n (\%) }\end{array}$ & $\begin{array}{l}\text { ASA- } \\
\text { n (\%) }\end{array}$ & p-value & ORa (CI à95\%) \\
\hline \multicolumn{5}{|l|}{ Duration of infertility } \\
\hline $1-2$ years & $4(12.12)$ & $7(21.21)$ & 0.2552 & $0.5123(0.1345-1.9520)$ \\
\hline 3 - 4 years & $11(33.33)$ & $7(21.21)$ & 0.2689 & $1.8571(0.6153-5.6056)$ \\
\hline$\geq 5$ years & $18(54.55)$ & $19(57.06)$ & 0.8041 & $0.8842(0.3343-2.3388)$ \\
\hline \multicolumn{5}{|l|}{ Testicular Trauma } \\
\hline Yes & $17(51.52)$ & $5(15.15)$ & 0.0017 & $5.9500(1.8446-19.1929)$ \\
\hline No & $16(48.48)$ & $8(84.85)$ & & \\
\hline \multicolumn{5}{|l|}{ Type of trauma } \\
\hline Violent testicular blow & $10(30.30)$ & $2(6.06)$ & 0.0106 & $6.7391(1.3455-33.7545)$ \\
\hline Cure of hernia & $10(30.30)$ & $3(9.09)$ & $0.0302^{*}$ & $4.3478(1.0722-17.6299)$ \\
\hline Testicular Torsion & $2(6.06)$ & $0(0.00)$ & $0.4923^{\star}$ & Not difined \\
\hline STDs & $14(42.42)$ & $5(15.15)$ & 0.0144 & $4.1263(1.2735-13.3700)$ \\
\hline \multicolumn{5}{|l|}{ Type of STDs } \\
\hline Chlamydia & $13(39.39)$ & $4(12.12)$ & 0.0112 & $4.7125(1.3405-16.5665)$ \\
\hline Syphilis & $3(9.09)$ & $2(6.06)$ & 0.6418 & $1.5500(0.2417-9.9400)$ \\
\hline $\mathrm{VIH}$ & $3(9.09)$ & $2(6.06)$ & 0.6418 & $1.5500(0.2417-9.9400)$ \\
\hline Leucospermia & $12(36.36)$ & $4(12.12)$ & 0.0423 & $4.1429(1.0406-19.7155)$ \\
\hline \multicolumn{5}{|l|}{ Culture of sperm } \\
\hline C. albicans & $6(18.18)$ & $2(6.06)$ & 0.1314 & $3.4444(0.6410-18.5082)$ \\
\hline S. aureus & $9(27.27)$ & $2(6.06)$ & 0.0207 & $5.8125(1.1477-29.4367)$ \\
\hline
\end{tabular}

${ }^{\star}$ Fisher Exact.

sleep because often busy managing their business and they would often have a high income exposing them to risky sexual behaviors [39], our results may be justified because short sleep and infections are associated with the presence of ACAS [29] [40] [41]. As for the jobless, who have almost nothing to do, they would generally have a long sleep, which is also associated with the presence of ASA [40].

Although the duration of infertility and the type of infertility increase the risk of STDs by increasing risky sexual behavior [42] [43] [44] and STDs are responsible for the production of ASA by antigenic community with the spermatozoa or by destruction of the blood-testicular barrier [45] [46], we found no association between the duration of infertility in men and ACAS positivity. Unlike us, Tennakoon V [47] found the association.

The history of testicular trauma including testicular torsion and cure of hernia were found in our study being high risks for positive ASA. In humans, the conditions destroying the blood-testis barrier are an obvious risk factor for ACAS production, as the immune system comes into direct contact with the antigens 
on the surface of the spermatozoon [48] [49] [50]. Štula I et al [51] found in their study that ASA increased significantly after hernioraphy. They explained this by 2 mechanisms. The first mechanism is ischemia that occurs during manipulation of the spermatic cord [52] [53]. The second mechanism is rupture of the blood-testis barrier resulting either from the direct lesion of the vas deferens or from its dilation [54] [55]. The occurrence of ASA during violent trauma is explained by ischemia. Indeed, after the violent trauma at the level of the testicles, there is a decrease in the perfusion of the traumatized area with contusion and ischemia. It follows the rupture of the blood-testicular barrier and production of ACAS [51] [56] [57].

In this study, we saw that past or current s sexual transmitted diseases multiply by 4.1 the risk of positive ASA but among STDs studied, only Chlamydia infection exposed at high risk of positive ASA. Microorganisms perform a range of fascinating adjustments to survive in the host. Among the various strategies used by microorganisms to overcome the host's immune response, molecular mimicry allows microorganisms to manipulate host physiology and cellular functions to their advantage by mimicking host proteins and initiating autoimmunity. This phenomenon has been studied globally in the context of autoimmune diseases; however, its implications have also been reported in infertility [57] [58] [59]. Witkin SS as well as Siam EM and Hefzy EM also found a strong correlation between positive ASA serology and that against C. trachomatis [60] [61]. Chronic infection of Chlamydia trachomatis has been shown to trigger an immune response in the male and female genital tract by antigenic community. Indeed, spermatozoa and chlamydia possess the hyperthermic shock protein Hsp60 which is associated with a humoral immune response. A humoral defense against C. trachomatis can also be directed against spermatozoa with production of ASA [14] [62] [63].

We noted that leucospermia multiplied by 4.1 the risk of positive ASA and that the presence of $S$. aureus in sperm culture multiplied by 5.8 the risk of ASA positivity. In their study, Elizabeth Martinez-Prado et al. [64] found that the presence of leukocytes in sperm was significantly correlated with an increase in cytokines IL-6, IL-8 and TNF-a and anti-HSP-60 antibodies. protein present on spermatozoa. It is known [65] [66] that the secretion of cytokines is one of the first signals of innate defense of the host to fight inflammation and infection of the genital tract by causing leukocyte chemotaxis at the site of inflammation and infection. The lymphocytes will thus come into contact with the spermatozoa and trigger the production of ASA [14]. In his study in Nigeria, Ekwere P.D found that in men with ASA, $S$. aureus was the most common germ found in culture [67].

\section{Conclusion}

This study shows that factors that may lead to risky sexual behavior and physical or infectious trauma are important risk factors for ASA positivity. It is therefore 
necessary to search for them systematically during male infertility in order to guide the search for ASA.

\section{Conflicts of Interest}

The authors declare no conflicts of interest regarding the publication of this paper.

\section{References}

[1] Practice Committee of the American Society for Reproductive Medicine (2013) Definitions of Infertility and Recurrent Pregnancy Loss: A Committee Opinion. Fertility and Sterility, 99, 63. https://doi.org/10.1016/j.fertnstert.2012.09.023

[2] WHO-ICMART (2009) International Committee for Monitoring Assisted Reproductive Technology (ICMART) and the World Health Organization (WHO) Revised Glossary of ART Terminology. Fertility and Sterility, 92, 1520-1524. https://doi.org/10.1016/j.fertnstert.2009.09.009

[3] Larsen, U. (2005) Research on Infertility: Which Definition Should We Use? Fertility and Sterility, 83, 846-852. https://doi.org/10.1016/j.fertnstert.2004.11.033

[4] Chachamovich, J.R., Chachamovich, E., Ezer, H., Fleck, M.P., Knauth, D., et al. (2010) Investigating Quality of Life and Health-Related Quality of Life in Infertility: A Systematic Review. Journal of Psychosomatic Obstetrics \& Gynecology, 31, 101-110. https://doi.org/10.3109/0167482X.2010.481337

[5] Bahamondes and Makuch (2014) Infertility Care and the Introduction of New Reproductive Technologies in Poor Resource Settings. Reproductive Biology and Endocrinology, 12, 87. https://doi.org/10.1186/1477-7827-12-87

[6] Wu, A.K., Elliott, P., Katz, P.P. and Smith, J.F. (2103) Time Costs of Fertility Care: The Hidden Hardship of Building a Family. Fertility and Sterility, 99, 2025-2030. https://doi.org/10.1016/j.fertnstert.2013.01.145

[7] Mubikayi, M.L., Mubikayi, N.N. and Kalengo, M.K. (2010) Stérilité du couple à l’institut Médicale chrétien du Kasaï. Annales Africains de Médecine, Kinshasa, 3, 426-431.

[8] Nana, P.N., Wandji, J.C., Fomulu, J.N., Mbu, R.E., Lekeet, R.J.I. and Woubinwou, M.J. (2011) Aspects psycho-sociaux chez les patients infertiles à la Maternite Principale. Mother and Child Health, 8, 5. https://doi.org/10.4303/cmch/C100601

[9] World Health Organization (1999) WHO Laboratory Manual for the Examination of Human Semen and Semen-Cervical Mucus Interaction. 4th Edition, Cambridge University Press, Cambridge, 1-86.

[10] Agarwal, A., Mulgund, A., Hamada, A. and Chyatte, M.R. (2015) A Unique View on Male Infertility around the Globe. Reproductive Biology and Endocrinology, 13, 37. https://doi.org/10.1186/s12958-015-0032-1

[11] Kumar, N. and Singh, A.K. (2015) Trends of Male Factor Infertility, an Important Cause of Infertility: A Review of Literature. Journal of Human Reproductive Sciences, 8, 191-196. https://doi.org/10.4103/0974-1208.170370

[12] Harris, I.D., Fronczak, C., Roth, L. and Meacham, R.B. (2011) Fertility and the Aging Male. Reviews in Urology, 13, e184-e190.

[13] Sabra, S.M. and Al-Harbi, M.S. (2014) An Influential Relationship of Seminal Fluid Microbial Infections and Infertility, Taif Region, KSA. World Journal of Medical Sciences, 10, 32-37. 
[14] Lu, J.-C., Huang, Y.-F. and Lu, N.-Q. (2008) Antisperm Immunity and Infertility. Expert Review of Clinical Immunology, 4, 113-126. https://doi.org/10.1586/1744666X.4.1.113

[15] Meinertz, H., Linnet, L., Fogh-Andersen, P., et al. (1990) Antisperm Antibodies and Fertility after Vasovasostomy: A Follow-Up Study of 216 Men. Fertility and Sterility, 54, 315-321. https://doi.org/10.1016/0165-0378(89)90139-3

[16] Naz, R.K. (2017) Antisperm Contraceptive Vaccine. In: Krause, W.K.H. and Naz, R.K., Eds., Immune Infertility, Springer, Berlin, 249-261. https://doi.org/10.1007/978-3-319-40788-3_17

[17] Naz, R.K. (2011) Antisperm Contraceptive Vaccines: Where We Are and Where We Are Going? American Journal of Reproductive Immunology, 66, 5-12. https://doi.org/10.1111/j.1600-0897.2011.01000.x

[18] Edwards, R.G. (1964) Immunological Control of Fertility in Female Mice. Nature, 203, 50-53. https://doi.org/10.1038/203050a0

[19] Castle, P.E., Whaley, K., Hoen, T.E., Moench, T.R. and Cone, R.A. (1997) Contraceptive Effect of Sperm-Agglutinating Monoclonal Antibodies in Rabbits. Biology of Reproduction, 56, 153-159. https://doi.org/10.1095/biolreprod56.1.153

[20] Shi, J., Yang, Z., Wang, M., et al. (2007) Screening of an Antigen Target for Immunocontraceptives from Cross-Reactive Antigens between Human Sperm and Ureaplasma urealyticum. Infection and Immunity, 75, 2004-2011. https://doi.org/10.1128/IAI.01171-06

[21] Yasin, A.L., Yasin, A.L. and Basha, W.S. (2016) The Epidemiology of Anti-Sperm Antibodies among Couples with Unexplained Infertility. Journal of Clinical and Diagnostic Research, 10, QC01-QC03. https://doi.org/10.7860/JCDR/2016/15788.7380

[22] Mahdi, B.M., Salih, W.H., Caitano, A.E., Kadhum, B.M. and Ibrahim, D.S. (2011) Frequency of Antisperm Antibodies in Infertile Women. Journal of Reproduction \& Infertility, 12, 261-265.

[23] Khatoon, M., Chaudhari, A.R., Singh, R. and Prajapati, S. (2011) Antisperm Antibodies in Primary and Secondary Infertile Couples of Central India. Biomedical Research, 22, 295-298.

[24] Clarke, G.N., Elliot, P.J. and Smaila, C. (1985) Detection of Sperm Antibodies in Semen Using the Immunobead Test: A Survey of 813 Consecutive Patients. American Journal of Reproductive Immunology, 7, 118-123.

https://doi.org/10.1111/j.1600-0897.1985.tb00269.x

[25] Cesaro, M., Valenti, M. and Massaccesi, A. (1985) Correlation between the Direct IgG MAR Test (Mixed Antiglobulin Reaction Test) and Seminal Analysis in Men from Infertile Couples. Fertility and Sterility, 44, 390-395. https://doi.org/10.1016/S0015-0282(16)48865-5

[26] Adejumo, B.I., Oke, A.A., Emokpae, M.A., Erhobor, T.A., Agba, M.I. and Oni, A. (2014) A Study of Antisperm Antibody among Infertile Subjects Investigated for Infertility in Lagos, Nigeria. Annals of Biomedical Sciences, 13, 29-35.

[27] Maindo, A.M.-A., Sihalikyolo, J., Agasa, S.B., O’yandjo, A.M., Mbutu, B., Bosunga, G.K. and Okenge, J.-P.M. (2019) Anti-Sperm Antibodies: Prevalence of Ig A and Ig G Positive Serology among Infertile Patients in Kisangani, Democratic Republic of Congo. Open Journal of Obstetrics and Gynecology, 9, 707-714. https://doi.org/10.4236/ojog.2019.95070

[28] Domagala, A., Havryluk, A., Nakonechnyj, A., et al. (2006) Antisperm Antibodies in Prepubertal Boys with Cryptorchidism. Archives of Andrology, 52, 411-416. 
https://doi.org/10.1080/01485010600822747

[29] Ou, J.P. and Zhuang, G.L. (2003) Effect of Antisperm Antibodies on Assisted Reproduction. National Journal of Andrology, 9, 214-217.

[30] Attia, K., Zaki, A., Eilts, B., et al. (2000) Antisperm Antibodies and Seminal Characteristics after Testicular Biopsy or Epididymal Aspiration in Dogs. Theriogenology, 53, 1355-1363. https://doi.org/10.1016/S0093-691X(00)00278-8

[31] Höbarth, K., Klingler, H.C., Maier, U. and Kollaritsch, H. (1994) Incidence of Antisperm Antibodies in Patients with Carcinoma of the Testis and in Subfertile Men with Normogonadotropic Oligoasthenoteratozoospermia. Urologia Internationalis, 52, 162-165. https://doi.org/10.1159/000282598

[32] Podzimek, S., Prochazkova, J., Pribylova, L., et al. (2003) Effect of Heavy Metals on Immune Reactions in Patients with Infertility. Casopis Lékaru Ceských, 142, 285-288.

[33] Podzimek, S., Prochazkova, J., Bultasova, L., et al. (2005) Sensitization to Inorganic Mercury Could Be a Risk Factor for Infertility. Neuroendocrinology Letters, 26, 277-282.

[34] Clark, S., Poulin, M. and Kohler, H.-P. (2009) Marital Aspirations, Sexual Behaviors, and HIV/AIDS in Rural Malawi. Journal of Marriage \& Family, 71, 396-416. https://doi.org/10.1111/j.1741-3737.2009.00607.x

[35] Glynn, J.R., Caraël, M., Suvé, A., Anagonou, S., Zekeng, L., Kahindo, M., et al. (2004) Does Increased General Schooling Protect against HIV Infection? A Study in Four African Cities. Tropical Medicine \& International Health, 9, 4-14. https://doi.org/10.1046/j.1365-3156.2003.01168.x

[36] Gregson, S., Waddell, H. and Chandiwana, S. (2001) School Education and HIV Control in Sub-Saharan Africa: From Discord to Harmony? Journal of International Development, 13, 467-485. https://doi.org/10.1002/jid.798

[37] Hargreaves, J.R., Bonell, C.P., Morison, L.A., Kim, J.C., Phetla, G., Porter, J.D.H., et al. (2007) Explaining Continued High HIV Prevalence in South Africa: Socioeconomic Factors, HIV Incidence and Sexual Behaviour Change among a Rural Cohort, 2001-2004. AIDS, 21, S39-S48. https://doi.org/10.1097/01.aids.0000300534.97601.d6

[38] Mmbaga, E.J., Leyna, G.H., Mnyika, K.S., Hussain, A. and Klepp, K.I. (2007) Education Attainment and the Risk of HIV-1 Infections in Rural Kilimanjaro Region of Tanzania, 1991-2005: A Reversed Association. Sexually Transmitted Diseases, 34, 947-953. https://doi.org/10.1097/OLQ.0b013e31813e0c15

[39] Keramat, A., Masoumi, S.Z., Mousavi, S.A., Poorolajal, J., Shobeiri, F. and Hazavehie, S.M.M. (2014) Quality of Life and Its Related Factors in Infertile Couples. Journal of Research in Health Sciences, 14, 57-64.

[40] Liu, M.-M., Liu, L., Chen, L., Yin, X.J., Liu, H., Zhang, Y.-H., Li, P.-L., Wang, S., Li, X.-X. and Yu, C.-H. (2017) Sleep Deprivation and Late Bedtime Impair Sperm Health through Increasing Antisperm Antibody Production: A Prospective Study of 981 Healthy Men. Medical Science Monitor, 23, 1842-1848. https://doi.org/10.12659/MSM.900101

[41] Hirano, Y., Shibahara, H., Koriyama, J., et al. (2011) Incidence of Sperm-Immobilizing Antibodies in Infertile Women with Past Chlamydia Trachomatis Infection. American Journal of Reproductive Immunology, 65, 127-132. https://doi.org/10.1111/j.1600-0897.2010.00883.x

[42] Fatusi, A. and Wang, W. (2009) Multiple Sexual Partnership Mediates the Associa- 
tion between Early Sexual Debut and Sexually Transmitted Infection among Adolescent and Young Adult Males in Nigeria. The European Journal of Contraception and Reproductive Health Care, 14, 134-143. https://doi.org/10.1080/13625180802601110

[43] Dhont, N., Muvunyi, C., Luchters, S., Vyankandondera, J., De Naeyer, L., Temmerman, M. and van de Wijgert, J. (2011) HIV Infection and Sexual Behaviour in Primary and Secondary Infertile Relationships: A Case-Control Study in Kigali, Rwanda. Sexually Transmitted Infections, 87, 28-34. https://doi.org/10.1136/sti.2010.042879

[44] Yazdi, R.S., Sene, A.A., Kohpaee, Z., Zadehmodaress, S., Hosseini, S.J. and Fallahian, M. (2009) The Correlation between Sexual Practices and the Development of Antisperm Antibodies. International Journal of Fertility and Sterility, 2, 189-192.

[45] Thaper, D. and Prabha, V. (2018) Molecular Mimicry: An Explanation for Autoimmune Diseases and Infertility. Scandinavian Journal of Immunology, 88, e12697. https://doi.org/10.1111/sji.12697

[46] Azizi, G., Namaki, S., Mirshafiey, A. and Hamid, K.M. (2015) HLA Antigens and Anti-Sperm Antibody Production in Iranian Vasectomized Men. Biomedical Research, 29, 87-90. https://doi.org/10.7555/JBR.20140113

[47] Tennakoon, V. (2012) Antisperm Antibodies and Their Effects on Infertility: A Sri Lankan Study on Antisperm Antibodies in Couples Undergoing Assisted Reproductive Technologies. LAP Lambert Academic Publishing, Riga, 76-79.

[48] Marconi, M. and Weidner, W. (2017) Site and Risk Factors of Antisperm Antibodies Production in the Male Population. In: Krause, W.K.H. and Naz, R.K., Eds., Immune Infertility, Springer, Berlin, 133-147. https://doi.org/10.1007/978-3-319-40788-3_8

[49] Tuech, J. (2012) Anticorps antispermatozoïdes: Indications, étiologies et applications en 2011, de l'exploration de l'infertilité au concept d'immunocontraception masculine. Andrologie, 22, 20-28. https://doi.org/10.1007/s12610-012-0165-4

[50] Koşar, A., Küpeli, B., Alçigir, G., Ataoglu, H., Sarica, K. and Küpeli, S. (1999) Immunologic Aspect of Testicular Torsion: Detection of Antisperm Antibodies in Contralateral Testicle. European Urology, 36, 640-644.

[51] Štula, I., Družijanić, N., Sapunar, A., Perko, Z., Bošnjak, N. and Kraljević, D. (2014) Antisperm Antibodies and Testicular Blood Flow after Inguinal Hernia Mesh Repair. Surgical Endoscopy, 28, 3413-3420. https://doi.org/10.1007/s00464-014-3614-7

[52] Harrison, R.G., Lewis-Jones, D.I., Moreno de Marval, M.J. and Connolly, R.C. (1981) Mechanism of Damage to the Contralateral Testis in Rats with an Ischaemic Testis. The Lancet, 2, 723-725. https://doi.org/10.1016/S0140-6736(81)91050-3

[53] Kearney, S.E. and Lewis-Jones, D.I. (1985) Effect of ACTH on Contralateral Testicular Damage and Cytotoxic Antisperm Antibodies after Unilateral Testicular Ischaemia in the Rat. Journal of Reproduction and Fertility, 75, 531-535. https://doi.org/10.1530/jrf.0.0750531

[54] Lee, R., Goldstein, M., Ullery, B.W., Ehrilch, J., Soares, M., Razzano, R.A., et al. (2009) Value of Serum Antisperm Antibodies in Diagnosing Obstructive Azoospermia. Journal of Urology, 181, 264-269. https://doi.org/10.1016/j.juro.2008.09.004

[55] Matsuda, T., Muguruma, K., Horii, Y., Ogura, K. and Yoshida, O. (1993) Serum Antisperm Antibodies in Men with Vas Deferens Obstruction Caused by Childhood Inguinal Herniorrhaphy. Fertility and Sterility, 59, 1095-1097.

https://doi.org/10.1016/S0015-0282(16)55934-2 
[56] Paltiel, H.J., Rupich, R.C. and Babcock, D.S. (1994) Maturational Changes in Arterial Impedance of the Normal Testis in Boys: Doppler Sonographic Study. American Journal of Roentgenology, 163, 1189-1193. https://doi.org/10.2214/ajr.163.5.7976898

[57] Apari, P., de Sousa, J.D. and Mülle, V. (2014) Why Sexually Transmitted Infections Tend to Cause Infertility: An Evolutionary Hypothesis. PLOS Pathogens, 10, e1004111. https://doi.org/10.1371/journal.ppat.1004111

[58] Anas, M., Utomo, D.H., Widjajanto, E., Sumarno, A. and Wiyasa, I.W.A. (2016) Molecular Modeling for Revealing Cross-Reaction Antibody with Staphylococcus aureus and Human Spermatozoa Protein. International Journal of ChemTech Research, 9, 233-239.

[59] Cunningham, M.W. (2016) Post-Streptococcal Autoimmune Sequelae: Rheumatic Fever and Beyond. In: Ferretti, J.J., Stevens, D.L. and Fischetti, V.A., Eds., Streptococcus pyogenes. Basic Biology to Clinical Manifestations, University of Oklahoma Health Sciences Center, Oklahoma City, 893-929.

[60] Witkin, S.S., Kligman, I. and Bongiovanni, A.M. (1995) Relationship between an Asymptomatic Male Genital Tract Exposure to Chlamydia trachomatis and an Autoimmune Response to Spermatozoa. Human Reproduction, 10, 2952-2955. https://doi.org/10.1093/oxfordjournals.humrep.a135827

[61] Siam, E.M. and Hefzy, E.M. (2011) The Relationship between Antisperm Antibodies Prevalence and Genital Chlamydia trachomatis Infection in Women with Unexplained Infertility. African Journal of Reproductive Health, 15, 93-101. https://doi.org/10.1016/j.mefs.2011.09.003

[62] Munoz, M.G., Jeremias, J. and Witkin, S.S. (1996) The $60 \mathrm{kDa}$ Heat Shock Protein in Human Semen: Relationship with Antibodies to Spermatozoa and Chlamydia trachomatis. Human Reproduction, 11, 2600-2603. https://doi.org/10.1093/oxfordjournals.humrep.a019177

[63] Mazumdar, S. and Levine, A.S. (1998) Antisperm Antibodies: Etiology, Pathogenesis, Diagnosis, and Treatment. Fertility and Sterility, 70, 799-810. https://doi.org/10.1016/S0015-0282(98)00302-1

[64] Martınez-Prado, E. and Bermudez, M.I.C. (2010) Expression of IL-6, IL-8, TNF-a, IL-10, HSP-60, Anti-HSP-60 Antibodies, and Anti-sperm Antibodies, in Semen of Men with Leukocytes and/or Bacteria. American Journal of Reproductive Immunology, 63, 233-243. https://doi.org/10.1111/j.1600-0897.2009.00786.x

[65] Fraczek, M. and Kurpisz, M. (2015) Cytokines in the Male Reproductive Tract and Their Role in Infertility Disorders. Journal of Reproductive Immunology, 108, 98-104. https://doi.org/10.1016/j.jri.2015.02.001

[66] Lotti, F. and Maggi, M. (2013) Interleukin 8 and the Male Genital Tract. Journal of Reproductive Immunology, 100, 54-65. https://doi.org/10.1016/j.jri.2013.02.004

[67] Ekwere, P.D. (1995) Immunological Infertility among Nigerian Men: Incidence of Circulating Antisperm Auto-Antibodies and Some Clinical Observations: A Preliminary Report. British Journal of Urology, 76, 366-370.

https://doi.org/10.1111/j.1464-410X.1995.tb07716.x 